\title{
Isolation and Characterization of Bacteriophages from Laban Jameed*
}

\author{
Murad Mohammad Ishnaiwer, Fawzi Al-Razem ${ }^{\#}$ \\ Biotechnology Research Center, Palestine Polytechnic University, Hebron, Palestine. \\ Email: "razemf@ppu.edu
}

Received July $25^{\text {th }}, 2013$; revised August $25^{\text {th }}, 2013$; accepted September $2^{\text {nd }}, 2013$

Copyright (C) 2013 Murad Mohammad Ishnaiwer, Fawzi Al-Razem. This is an open access article distributed under the Creative Commons Attribution License, which permits unrestricted use, distribution, and reproduction in any medium, provided the original work is properly cited.

\begin{abstract}
Laban jameed is a dried salty dairy product obtained by fermentation of milk using a complex population of lactic acid bacteria. Jameed is considered a traditional food product in most eastern Mediterranean countries and is usually made from sheep or cow milk. The aim of this study was to assess phage contamination of jameed dairy product. Two phages were isolated: one from sheep milk jameed (PPUDV) and the other from cow milk jameed (PPURV). Each of the two bacteriophages was partially characterized. The PPUDV phage was identified as a single stranded DNA virus with an approximately $20 \mathrm{~kb}$ genome that was resistant to RNase, whereas PPURV phage possessed a double stranded RNA genome of approximately $20 \mathrm{~kb}$ and was resistant to DNase. The phage bacterial strain hosts were identified as Lactobacillus helveticus and Bacillus amyloliquefaciens for PPUDV and PPURV, respectively. One step growth curve using a double layer plaque assay test was carried out to monitor the phage life cycle after host infection. PPUDV showed a latent period of about $36 \mathrm{~h}$, burst period of $70 \mathrm{~h}$ and a burst size of about 600 Plaque Forming Units (PFU) per infected cell. PPURV phage showed a latent period of about $24 \mathrm{~h}$, burst period of $47 \mathrm{~h}$ and a burst size of about 700 PFU per infected cell. SDS-PAGE analysis of total viral proteins showed at least three major bands $(27,40$, and $45 \mathrm{kDa})$ for PPUDV. This is the first study to report the isolation of both DNA and RNA bacteriophages from laban jameed. This study adds new insights into the complexity of dairy contamination and fermentation microbiology of the jameed revealing the existence of two viral genomes in this highly dried and salty dairy product.
\end{abstract}

Keywords: Lactic Acid Bacteria; Bacteriophages; Laban Jameed; DNA Viruses; RNA Viruses

\section{Introduction}

Laban jameed is a dried and salty dairy product that forms part of an ancient traditional diet that is common in the Middle East, particularly in Syria, Lebanon, Jordan, Saudi Arabia and Palestine [1-3]. It is favored by Bedouin communities because of the ease of storing this dairy product for a long period of time and due to its high stability and resistance to pathogens. Jameed is traditionally made from sheep and/or cow fermented milk and is used in many Arab food dishes, such as Mansaf [1,2]. Milk fermentation occurs mostly through the action of a highly complex microflora of lactic acid bacteria (LAB) through continuous shaking, leading to a highly acidic

\footnotetext{
"Authors' contribution: M.M-I carried out the experimental work and provided the first draft of the manuscript. F. Al-R designed and supervised the work. Both authors have read and approved the final manuscript.

${ }^{\#}$ Corresponding author.
}

product, formation of butter (curd) and expulsion of the milk serum liquid (whey). The curd is then slightly heated to accelerate the onset of the fermentation process and to further ensure the full separation of whey. The whey is decanted and the curd is added into a cheesecloth container to remove the excess water. When it becomes a thick paste, called labaneh in Palestine, it is kneaded or sprinkled with sodium chloride salt (approximately 10\% salt contents) and placed to dry for a few days in the sun to ensure that no dampness occurs, which could spoil the product [1-3].

In most processed dairy products, the fermentation of milk is facilitated by using a mixture of LAB, such as Lactobacillus acidophilus, L. brevis, L. casei, L. fermentum, L. kefir, L. parakefir, L. plantarum, and L. helviticus $[4,5]$. Lactic acid bacteria are generally gram positive and acid tolerant and producing lactic acid as a final product of carbohydrate fermentation $[5,6]$. Similar to 
many other bacterial species, the LAB are susceptible to several types of bacteriophages and some of these phage particles have been isolated and characterized [5-8]. Most LAB known phages are tailed and are members of the Caudovirales order [8].

With the expanding dairy product industries, phage contamination is a growing problem. This contamination is believed to affect the fermentation process and the quality of dairy product $[6,9]$. Contamination could originate from different sources, such as water, soil, air, cattle feces, cattle udder and milk equipment [1,9]. The phage contamination in dairy products becomes problematic to dairy industries even with a minute amount of phage particles due to phage ability to rapidly increase its numbers once a bacterial host is available. To add to this problem, phages usually tolerate high acidity and high temperature values during the pasteurization process. Phages can cause a collapse of the lactose-lactic acid pathway and decrease the overall efficiency of the fermentation process. These problems are detrimental to dairy product quality and often make the food products susceptible to spoilage by additional bacterial invasion, which can further hurt the fermentation process $[1,6]$.

Lactic acid bacteria adapted and modified a variety of anti-phage defense mechanisms to escape phage infections. Such mechanisms were mostly observed against dsDNA phages [8,10,11]. Phages, however, utilize several tricky circumventions that were reported to suppress those mechanisms $[8,9,11]$. The most common bacterial anti-phage defense mechanisms are developed to suppress phage adsorption, DNA injection and recruitment of restriction modification systems. Accordingly, bacteria use specific proteins that mask the phage recognition site receptor located at bacterial cell surface or even invoke a conformational change, which causes phages to mistake their attachment point. In addition, bacteria can alternatively mask their receptors through secreting specific sugar residues called exopolysaccharides, which help in inhibiting phage adsorption. Phages, however, can predominantly secrete specific polysaccharide degrading enzymes called lyases that degrade those bacterial residues $[8,10,11]$.

Moreover, some LAB generate bacteriophage-insensitive mutants (BIMs) in which a cascade of phage mutations results in the alteration of recognition sites that inhibit bacteriophage adsorption. Such point mutations have been reported in chromosomal genes coding for Lactococcus cell receptors [8,10,11]. Mutant phages could, however, overcome this modification and infect those resistant bacteria. In some cases, if bacteria couldn't inhibit phage adsorption, they instead secret other specific proteins that affect genome translocations to the cytoplasm through changing the injection site and blocking the cell wall degradation $[8,10,11]$. Otherwise, if phage genomes are able to adapt to these challenges and successfully pass through the cytoplasm, bacteria recruit other further defense mechanisms termed as restriction-modification systems to degrade unmethylated genomes at specific sites.

Due to multiple antibiotic-resistant bacteria, the use of bacterial viruses, i.e., bacteriophage therapy as alternative to conventional antibiotics is rapidly increasing. Bacteriophages can be more specific than antibiotics. One advantage of phage therapy is the specificity of targeting only the host bacterial cells, while antibiotics could also kill a wide range of bacteria in addition to the targeted harmful one [9]. In addition, there are no reported cases of side effects following the use of LAB phages, unlike most antibiotics that may enhance the side effects [9].

The aim of this study was to isolate and characterize jameed milk bacteriophages and identify their host cells. To our knowledge this study represents the first isolation of ssDNA and dsRNA bacteriophages from dairy sources.

\section{Materials and Methods}

\subsection{Laban Jameed Bacterial Culture}

Samples of laban jameed used in this study were obtained from the cities of Tulkaram (north) and Dahriya (south) of Palestine. The Tulkaram jameed was made of cow fermented milk, whereas the Dahriya jameed was made of sheep fermented milk. The isolated bacteriophages were named after the Palestine Polytechnic University (PPU) and its nucleic acid composition: PPUDV (PPU DNA Virus) for phage isolated from Dahriya jameed and PPURV (PPU RNA Virus) for phage isolated from jameed obtained from the city of Tulkaram. Jameed samples were stored at $-80^{\circ} \mathrm{C}$ until they were processed.

From each jameed sample, a small piece of approximately 1.0 gram was incubated for 2 days at $37^{\circ} \mathrm{C}$ with continuous shaking at $200 \mathrm{rpm}$ in $100 \mathrm{ml}$ skim milk

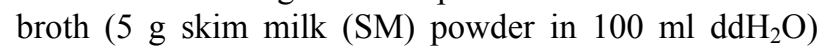
until the O.D at $600 \mathrm{~nm}$ reached 0.2. This was followed by plating $200 \mu \mathrm{l}$ from each culture on SM agar plates (100 $\mathrm{ml} \mathrm{SM}$ broth added to it $1 \mathrm{~g}$ agar). Individual colonies were then picked and re-cultured separately in new flasks containing $100 \mathrm{ml} \mathrm{SM}$ broth to examine the lysis of the bacteriophages. All bacterial stock cultures were stored at $-80^{\circ} \mathrm{C}$ in $\mathrm{SM}$ containing $16 \%$ (v/v) glycerol. When needed, frozen culture stock was allowed to thaw and used to prepare an overnight culture in SM broth before plating $200 \mu \mathrm{l}$ from the overnight culture on SM agar plates.

\subsection{Phage Isolation}

Fifty $\mathrm{ml}$ of two cultures of SM broth inoculated with a 
piece of jameed milk were tested for the presence of phages. To ensure purified phage filtration from bacteria, 5 drops of chloroform were added to each sample, stored for $15 \mathrm{~min}$ at room temperature before centrifugation at 13,000 rpm for $5 \mathrm{~min}$. This step was repeated twice to ensure that sufficient phage particles were purified. The supernatant was then transferred to a new microfuge tube and re-centrifuged again. It was finally filtered through $0.45 \mu \mathrm{m}$ sterile filters and filtrates were named according to the sample origin.

Phage filtrates were added upon overnight bacterial culture plated on SM agar plates to monitor phage sensitivity (lysis) or resistance (no lysis). Phage filtrates from Tulkaram region were tested on both Tulkaram and Dahriya bacterial colonies and the same was done to the Dahriya filtrate. As a control, each time a tube containing only bacteria without phage filtrates was used in each manipulation, plates were kept for $15 \mathrm{~min}$ in a laminar flow hood to dry, before incubation at $37^{\circ} \mathrm{C}$ up to 3 days until phage lysis was detected. Each bacteriophage lysis was carried out for at least three subsequent times until a pure phage was obtained. A small piece of each lysis was stored in a small $1.5 \mathrm{ml}$ Eppendorf tube in $-80^{\circ} \mathrm{C}$ freezer as a stab culture.

\subsection{Characterization of the Host Bacteria and Marker Analysis}

Genomic DNA for each bacterial host that showed sensitivity to phage lysis was extracted using EZ-DNA Kit (Biological Industries, Cat\# 20-600-50). The primer sequences for the two markers used to identify the host strains isolated from the Jameed are shown in (Table 1). The two markers were the recA gene, which is considered specific for LAB and the gene encoding the 16S rRNA. For both recA and 16S rRNA genes, the PCR reaction contained $1 \mu \mathrm{l}$ of template DNA for each host colony, 2.5 $\mu \mathrm{l}$ of $10 \mathrm{x}$ PCR reaction buffer, $0.5 \mu \mathrm{M}$ of each primer $(10$ pmol concentration), $2.5 \mu \mathrm{l}$ of $20 \mathrm{mM} \mathrm{MgSO}_{4}, 0.5 \mu \mathrm{l}$ of 20 $\mathrm{mM}$ dNTPs and $1.25 \mathrm{U}$ of thermostable Taq polymerase. The mixture volume was completed with ultrapure water

Table 1. Primer sequences used to amplify the marker genes, rec $A$ and $16 \mathrm{~S}$ rDNA partial sequences. Information in relative to their sequences and size of amplified fragment are included.

\begin{tabular}{ccc}
\hline Name & Sequence & Length \\
\hline recA reverse & 5 '-T TY ATHGAY GCN GAR CAY GC-3' & 340 bp \\
recA forward & 5'-CCW CCW GKWGTHGTYTCNGG-3' & \\
$\begin{array}{c}\text { 16S rDNA } \\
\text { reverse }\end{array}$ & 5 '-GGACTACCAGGGTATCTAAT-3' & \\
$\begin{array}{c}\text { 16S } r D N A \\
\text { forward }\end{array}$ & 5'-AGTTTGATCCTGGCTCAG-3 & \\
\hline
\end{tabular}

$\mathrm{Y}$ for $(\mathrm{C}$ or $\mathrm{T}), \mathrm{H}$ for $(\mathrm{A}$ or $\mathrm{C}$ or $\mathrm{T}), \mathrm{R}$ for $(\mathrm{A}$ or $\mathrm{G}), \mathrm{W}$ for $(\mathrm{A}$ or $\mathrm{T}), \mathrm{N}$ for (A or $\mathrm{C}$ or $\mathrm{G}$ or $\mathrm{T}), \mathrm{M}$ for (A or $\mathrm{C}), \mathrm{K}$ for ( $\mathrm{G}$ or $\mathrm{T})$. to a final volume of $25 \mu \mathrm{l}$. Amplification of the recA gene was conducted using the following conditions: initial denaturation was performed at $94^{\circ} \mathrm{C}$ for $3 \mathrm{~min}$ and for 30 sec for the subsequent 30 cycles, followed by $30 \mathrm{sec}$ for primer annealing at $54^{\circ} \mathrm{C}$, elongation of the target gene with taq polymerase at $72^{\circ} \mathrm{C}$ for $30 \mathrm{sec}$. A final extension of $5 \mathrm{~min}$ at $72^{\circ} \mathrm{C}$ was followed by cooling down to $4^{\circ} \mathrm{C}$. The 16S rRNA PCR reaction conditions were as follows: $95^{\circ} \mathrm{C}$ for $5 \mathrm{~min}$ for the initial denaturation, $1 \mathrm{~min}$ denaturation for the subsequent 30 cycles, primer annealing at $51^{\circ} \mathrm{C}$ for $1 \mathrm{~min}$, target elongation at $72^{\circ} \mathrm{C}$ for $1.30 \mathrm{~min}$. A final extension of $10 \mathrm{~min}$ at $72^{\circ} \mathrm{C}$ was followed by cooling down to $4^{\circ} \mathrm{C}$. For gene sequencing, PCR product purification was achieved by following instructions provided in the AccuPrep PCR Purification Kit (Bioneer K-3035).

DNA sequences of the isolated DNA markers were aligned manually, then similarity trees were constructed using UPGMA method with MEGA V.5 software.

\subsection{Bacteriophage Genome Isolation}

Bacteriophage genomes were extracted according to a protocol developed by Manasra and Barghouthi [12] with minor modifications as follows. Two volumes $(1000 \mu \mathrm{l})$ of saturated ammonium sulfate containing $0.1 \%$ of 2 mercaptoethanol were mixed with the phage filtrate (500 $\mu \mathrm{l})$ for $5 \mathrm{~min}$. Supernatant was removed after centrifuging at $13,000 \mathrm{rpm}$ for $5 \mathrm{~min}$ at $4^{\circ} \mathrm{C}$. The pellet was then dissolved in $0.2 \mathrm{ml} \mathrm{1 \%} \mathrm{SDS} \mathrm{and} 0.2 \mathrm{ml} 0.5 \mathrm{~N} \mathrm{NaOH}$ and centrifuged at $13,000 \mathrm{rpm}$ for $5 \mathrm{~min}$. To the clear supernatant, $0.4 \mathrm{ml}$ of $3 \mathrm{~N}$ sodium acetate was added in addition to 0.6 volume of isopropanol to precipitate the genome, and then held for $15 \mathrm{~min}$ at room temp. The mixture was then centrifuged at $13,000 \mathrm{rpm}$ for $10 \mathrm{~min}$ and the resulting pellet was incubated with $100 \mu \mathrm{g} / \mu \mathrm{l}$ of proteinase $\mathrm{K}$ at $37^{\circ} \mathrm{C}$ for $30 \mathrm{~min}$. Finally, the phage genome was precipitated using $70 \%$ ethanol and the pellet was collected in $0.2 \mathrm{ml} \mathrm{TE}$ buffer after 2 min centrifugation at $8000 \mathrm{rpm}$.

\subsection{Bacteriophage Genome Characterization}

The entity of nucleic acids was determined via the treatment of phage genome with DNase and RNase. Ten $\mu$ of each genome sample was incubated with $3 \mu$ of DNase and the same with RNase for $35 \mathrm{~min}$ at $37^{\circ} \mathrm{C}$. The mixture was then loaded on $0.7 \%$ agarose gel using undigested genome as a control, and lambda phage ge nometreated with HindIII restriction enzyme was used as a high molecular weight ladder.

The RNase A treatment at low and high concentrations was used to determine ss/ds RNA genomes according to the following references [13-17]. Briefly, $10 \mu \mathrm{l}$ of PPURV genome were incubated with $3 \mu \mathrm{l}$ RNase A either with low $(0.1 \mathrm{M})$ or high $(0.4 \mathrm{M}) \mathrm{NaCl}$ concen- 
tration for $1 \mathrm{~h}$ at $37^{\circ} \mathrm{C}$. Following treatment, samples were mixed with $6 \times$ loading dye and loaded on $0.7 \%$ agarose gel as above. To determine whether phage genomes belong to dsDNA or ssDNA, $10 \mu \mathrm{l}$ of genome was boiled for $6 \mathrm{~min}$, placed on ice, before rapidly being loaded on a $0.7 \%$ gel electrophoresis with un-boiled genome as a control and lambda phage genome was used as a ladder.

Furthermore, isolated genomes were treated with a set of specific dsDNA restriction enzymes including, MluI, BamHI, EcoRI, HindIII and PvuI following protocols provided by the manufacture. Briefly, the same reaction mixture of $20 \mu \mathrm{l}$ was prepared for all restriction enzymes at which $16 \mu \mathrm{l}$ nuclease-free water was mixed with $2 \mu \mathrm{l}$ $10 \times$ buffer, $1 \mu \mathrm{l}$ from each restriction enzyme and $1 \mu \mathrm{l}$ of DNA template. Samples were then incubated at $37^{\circ} \mathrm{C}$ for 8 and $16 \mathrm{~h}$ periods before the reaction mixtures were loaded on a $1 \%$ agarose gel.

The SDS-PAGE was carried out according to $[18,19]$. Total phage proteins were separated on a $10 \%$ SDSPAGE, stained with $0.1 \%$ (w/v) Coomassie Brilliant Blue (Applichem/ A3480,0010) before documentation using a digital camera.

\subsection{One Step Growth Curve}

The double layer Plaque assay method was used according to published work [20,21] as follows: Previously prepared high titer filtrates were used, a single plaque was picked up from an agar plate, mixed with log phase bacteria $\mathrm{O}^{\mathrm{D}} \mathrm{D}_{600} \mathrm{~nm}$ of 0.2 , and then incubated for 3 hours. Samples were then purified as above and used for one step growth curve. 10-fold serial dilutions were performed with each dilution prepared by mixing $0.1 \mathrm{ml}$ of stock phage suspension in $0.9 \mathrm{ml}$ water (tube labeled as tube 1). The $0.1 \mathrm{ml}$ from tube 1 sample was transferred into tube 2 , filled with $0.9 \mathrm{ml}$ water; the same was done for the other remaining dilutions. From each titer, $0.1 \mathrm{ml}$ bacteriophage suspension dilution was inoculated to $0.5 \mathrm{ml}$ of $\mathrm{O}_{\mathrm{D}} \mathrm{D}_{600} \mathrm{~nm}=0.2$ bacterial culture, incubated at $37^{\circ} \mathrm{C}$ for $40 \mathrm{~min}$, and then added to a tube containing 3 $\mathrm{ml}$ of $0.7 \%$ soft agar heated at $49^{\circ} \mathrm{C}$ and gently mixed. Finally it was poured onto a separated prepared monolayer SM plate. Plates were then incubated upside down at $37^{\circ} \mathrm{C}$. Plaque formation was monitored and data were recorded.

\section{Results}

\subsection{Isolation of Bacterial Strains and Phage Filtrates}

Three bacterial colonies from each skimed milk agar plate representing different jameed samples (see M\&M Section 2.1) were selected for further testing against phage filtrates. Each colony was labeled in reference to the bacteria (B) and colony number $(1-6)$, (i.e., BC1 for bacteria colony $1, \mathrm{BC} 2$ for bacteria colony 2 , etc.). Thus, the bacterial colonies $\mathrm{BC} 1, \mathrm{BC} 2, \mathrm{BC} 3$ were selected from Dahriya samples, whereas $\mathrm{BC} 4, \mathrm{BC} 5, \mathrm{BC} 6$ were selected from Tulkaram samples. Phage filtrates were prepared from jameed samples as described above. Filtrates were tested against all bacterial colonies from both cities, Dahriya virus was tested on Tulkaram and Dahriya, the same was done for the other filtrate.

Screening of phage filtrate effects on the bacterial lawns showed two clear round plaques, each with approximately $1.5 \mathrm{~cm}$ diameter (Figure 1). The viruses which could cause the plaques were named PPUDV for phage isolated from Dahriya sheep milk jameed (Figure 1(a)) and PPURV for phage isolated from Tulkaram cow milk jameed (Figure 1(b)). The PPUDV bacteriophage propagated on bacterial colony 1 (BC1), while PPURV bacteriophage lysis bacteria colony 4 (BC4) bacterial hosts, the results were confirmed by triplicate experiments. In each case, a control plate consisting of bacterial strain devoid of phage was prepared. Separated plates with two sides were used, for example bacterial colony 1 cultured on both sides of the plate, then drops of phage filtrates spotted on one of the sides, while keeping the other side as a control with just bacteria without virus.

\subsection{Characterization of Phage Host Bacteria}

To identify the bacteria which were susceptible to phage lysis, two marker genes for the $16 \mathrm{~S} r R N A$ and recA were amplified from genomic DNA isolated from the BC4 and BC1 host bacteria. The PCR amplification results showed clear bands matching the expected sizes of the two fragments (Figures 2(a) and (b)).

The partial sequences targeted, as commonly assessed

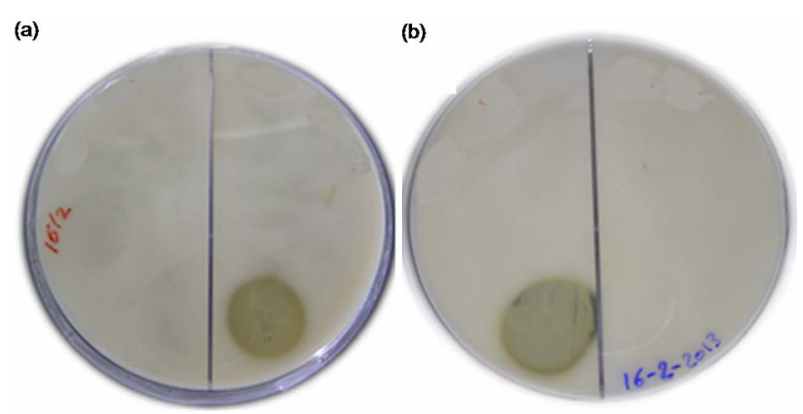

Figure 1. Bacterial cultures on skim milk plates showing bacteriophage lysis. Phage filtrate $(30 \mu \mathrm{l})$ was added to each bacterial colony. (a) The PPUDV phage was able to lyse the bacterial host (BC1) isolated from jameed made of sheep fermented milk. Lysis appeared as a clear circle at the right side. The left side is a control with the host bacteria, but with no phage added. (b) the PPURV phage lysed the bacterial host (BC4) isolated from jameed made of cow fermented milk with clear circle at the left side. The right side represents the control host bacteria showed no lysis. 


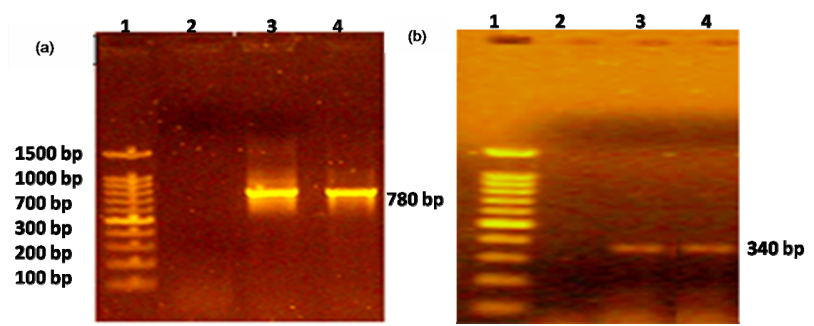

Figure 2. Amplification of two marker genes from the BC4 and BC1 host cells. Amplicons were separated on $1.5 \%$ agarose gel and visualized by ethidium bromide staining according to standard protocols [18] using $1.5 \mathrm{~kb}$ DNA Ladder. (a) PCR results of the $16 \mathrm{~S}$ rRNA partial sequence shows the expected fragment size of $780 \mathrm{bp}$. Lane 1: DNA ladder (Promega/G5711), lane 2 is a negative control (master mix with no DNA template). Lanes $3 \& 4$ show the $16 S$ rRNA amplicons for $\mathrm{BC} 4$ and $\mathrm{BC}$, respectively. (b) PCR results of the rec $A$ gene partial sequence. Lane 1 shows the DNA ladder (Promega/G5711) Lane 2 is a negative control (master mix with no DNA template). Lanes $3 \& 4$ show the rec $A$ gene amplicon for $\mathrm{BC} 4$ and $\mathrm{BC} 1$, respectively.

by PCR amplification for the $16 \mathrm{~S}$ rRNA and recA were approximately (780 bp and $340 \mathrm{bp}$ ), respectively.

The purified gel products for the two genes, 16S rRNA and $\mathrm{rec} A$ were sequenced in the Hereditary Research Laboratory/Life Science Department/Bethlehem University. The identity for each sequence was determined and confirmed by Blast analysis and by aligning against available sequences on the GenBank

(http://blast.ncbi.nlm.nih.gov/Blast.cgi) using BLAST N program. Both host bacteria were identified by matching the sequence with the highest maximum identity score.

To determine the relationship of the host strains with $\mathrm{LAB}$ that are mostly found in dairy products, multiple sequence alignments for both recA and 16S rRNA sequences were constructed using the CLUSTAL W software. Then phylogenetic trees were constructed using UPGMA method with MEGA V.5 software comprising all highly similar alignments, most common dairy bacteria and $\mathrm{BC} 4, \mathrm{BC} 1$ recA and $16 \mathrm{~S}$ rRNA sequences, to better illustrate the homology with available bacterial strains (Figures 3 and 4). All closely related sequences were obtained from the National Center for Biotechnology Information (NCBI) databases. In addition, the 16S rRNA and recA partial sequences of the Streptococcus thermophilus (a gram positive bacteria that play a role in milk fermentation) were used, because several phylogenetic studies recommended its use as an outgroup, since other LAB strains are too closely related to serve as a suitable phylogenetic outgroup $[22,23]$. From the marker analyses of the two genes encoding the 16S rRNA and recA, results showed that the $\mathrm{BC} 4$ host is a close relative to the Bacillus amyloliquefaciens (Figures 3(a) and (b)), whereas the $\mathrm{BC} 1$ is a close relative to the Lactobacillus helveticus strain (Figures 4(a) and (b)).
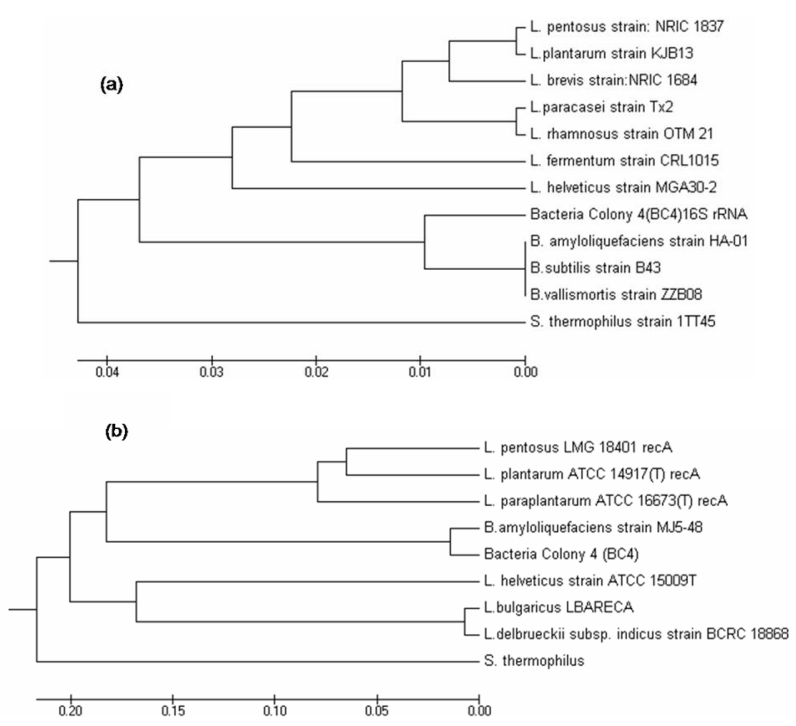

Figure 3. The phylogenetic trees for $\mathrm{BC} 4$ using marker genes of the 16S rRNA (a) and recA (b). Trees were constructed using UPGMA method. Trees were built using high sequence similarity from the alignment with the most common LAB sequences form GenBank. Streptococcus thermophilus was used as an outgroup as shown. The recA of BC4 clustered with Bacillus amyloliquefaciens, whereas in $16 \mathrm{~S}$ rRNA tree, it was difficult to determine whether $\mathrm{BC} 4$ did actually belong to Bacillus amyloliquefaciens.
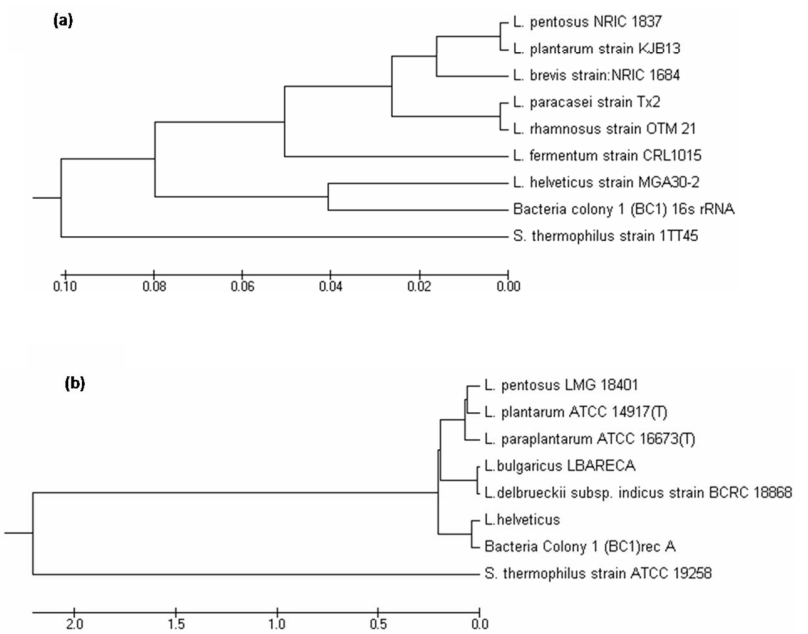

Figure 4. The phylohenetic trees for BC1 using marker genes of the 16S rRNA (a) and recA (b). Trees were constructed using UPGMA method. Streptococcus thermophilus was used as an outgroup as shown. The recA and $16 \mathrm{~S} r$ RNA phylogenetic trees of the $\mathrm{BC} 1$ clustered with the Lactobacillus helveticus, one of the common LAB.

\subsection{Characterization of Isolated Bacteriophages}

Two phages representing RNA and DNA genomes were isolated. The PPURV bacteriophage that was able to cause lysis to (Bacillus amyloliquefaciens) was found to be an RNA bacteriophage as it was sensitive to RNase and resistant to DNase digestion (Figure 5(a)). The PPUDV, 
on the other hand, was a DNA bacteriophage sensitive to DNase, but resistant to RNase digestion (Figure 5(b)). Genome sizes, however, seemed to be very similar, approximately $20 \mathrm{~kb}$ each (Figure 5).

Confirmation that the PPURV genome is dsRNA comes from it being sensitive to RNase A digestion at low $\mathrm{NaCl}$ treatment, but was resistant to RNase A treatment at high $\mathrm{NaCl}$ concentration (Figure 6(a)). The PPUDV bacteriophage genome, on the other hand, was a ssDNA as confirmed by agarose gel. Boiled and un-boiled genomes migrated to the same distance on the agarose gel (Figure 6(b)).

\subsection{One Step Growth Curve of the Isolated Bacteriophages}

To reveal the nature of virus replication upon infection of host bacteria, one step growth curve assays were designed to allow estimating the titers of bacteriophage stocks through using a "Plaque Forming Assay" (PFU). This reflects how much the original infected cells release viral progeny. Consequently, the titer calculation in PFU/ml were obtained through multiplying the number of plaques with dilution factor then dividing on the inoculum volume [24]. It relies first on constructing a table showing each titration with the resulting plaques. This helps in measuring the (PFU) as previously described as only the first titration is capable of forming plaques.

The data from the plaque assays were analyzed. The number of PFU per bacterial cell was plotted on the $\mathrm{Y}$ axis against time required to form plaques on the $\mathrm{X}$ axis. Consequently, for each bacteriophage, the latent, burst period and burst size were as a result determined (Figure 7). For PPURV phage, the latent period was about $24 \mathrm{~h}$, burst period was $47 \mathrm{~h}$ and the burst size was about 700
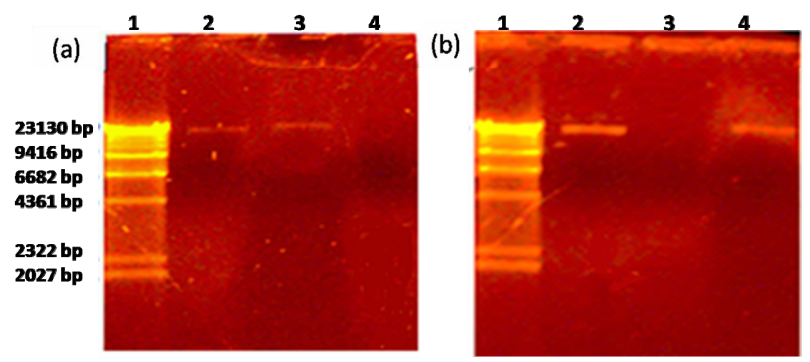

Figure 5. Identity and sizes of PPUDV and PPURV bacteriophages. Both genomes were treated with DNase and RNase before they were loaded on $0.7 \%$ agarose gel electrophoresis. (a) the PPURV genome is an RNA phage. Lane1 contains $23 \mathrm{~kb}$ ladder and lane 2 contains undigested PPURV genome. Lane 3 contains PPURV genome treated with DNase and Lane 4 the PPURV genome treated with RNase. (b) the PPUDV genome is a DNA phage. Lane 1 contains a $23 \mathrm{~kb}$ ladder and lane 2 contains the undigested PPUDV genome. Lane 3 contains PPUDV genome treated with DNase and Lane 4 PPUDV genome treated with RNase.
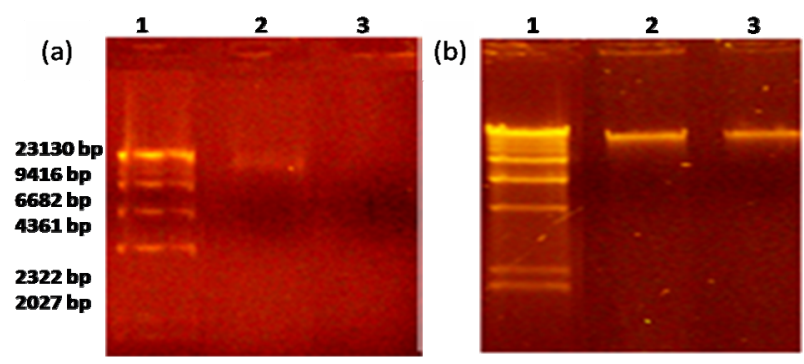

Figure 6. The PPURV is a dsRNA whereas PPUDV is a ssDNA phage. (a) Lane 1 contains a $23 \mathrm{~kb}$ ladder, lane 2 contains the PPURV genome treated with RNase $A$ in the presence of $0.4 \mathrm{M} \mathrm{NaCl}$ and lane 3 contains the PPURV genome treated with $\mathrm{RNase}$ (a) at $0.1 \mathrm{M} \mathrm{NaCl}$. (b) the PPUDV is a ssDNA phage. Lane 1 contains a $23 \mathrm{~kb}$ ladder, lane 2 contains the PPUDV genome incubated on ice and Lane 3 contains PPUDV genome after $6 \mathrm{~min}$ incubation in boiling water. All treatments and ladders were loaded on $0.7 \%$ agarose gels.

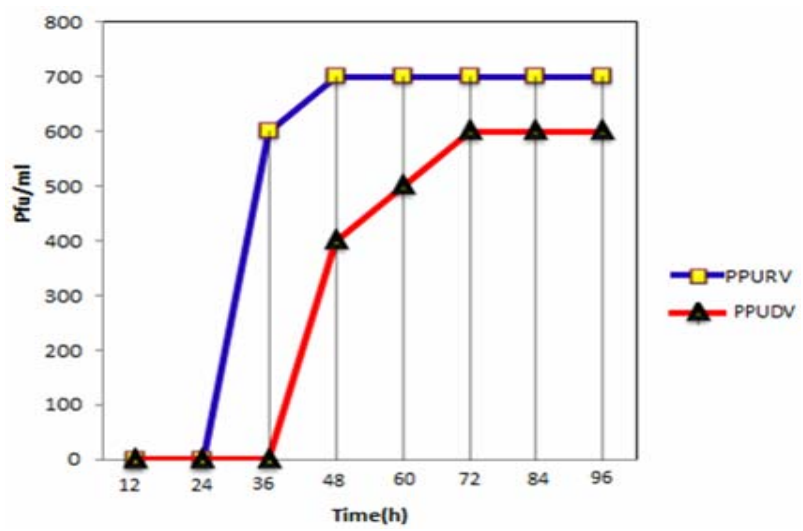

Figure 7. One step growth curves for PPUDV and PPURV bacteriophages. The curves showed the latent, burst period and burst size for each phage through its replication after bacteria intrusion. It is based on counting the number of formed plaques that were developed, then measuring PFU and comparing it against time. Results are the measure of three time trials. For PPURV phage, the latent period was about $24 \mathrm{~h}$, burst period was $47 \mathrm{~h}$ and the burst size of approximately 700 PFU per infected cell. Whereas, the latent period for PPUDV was about $36 \mathrm{~h}$ with burst period of about $70 \mathrm{~h}$ and a burst size of about $600 \mathrm{PFU} /$ infected cell.

PFU per infected cell. Whereas, the latent period for PPUDV was about $36 \mathrm{~h}$ with burst period of about $70 \mathrm{~h}$ and a burst size of about $600 \mathrm{PFU} /$ cell.

\subsection{SDS-PAGE Analysis of the Isolated PPUDV Bacteriophage}

The phage total proteins were analyzed on SDS-PAGE. Samples were electrophoresed on a $10 \%$ polyacrylamide gel in the presence of SDS. Stained gels showed three distinct protein bands for PPUDV phage particles (Figure 8). The band sizes were estimated to be approxi- 


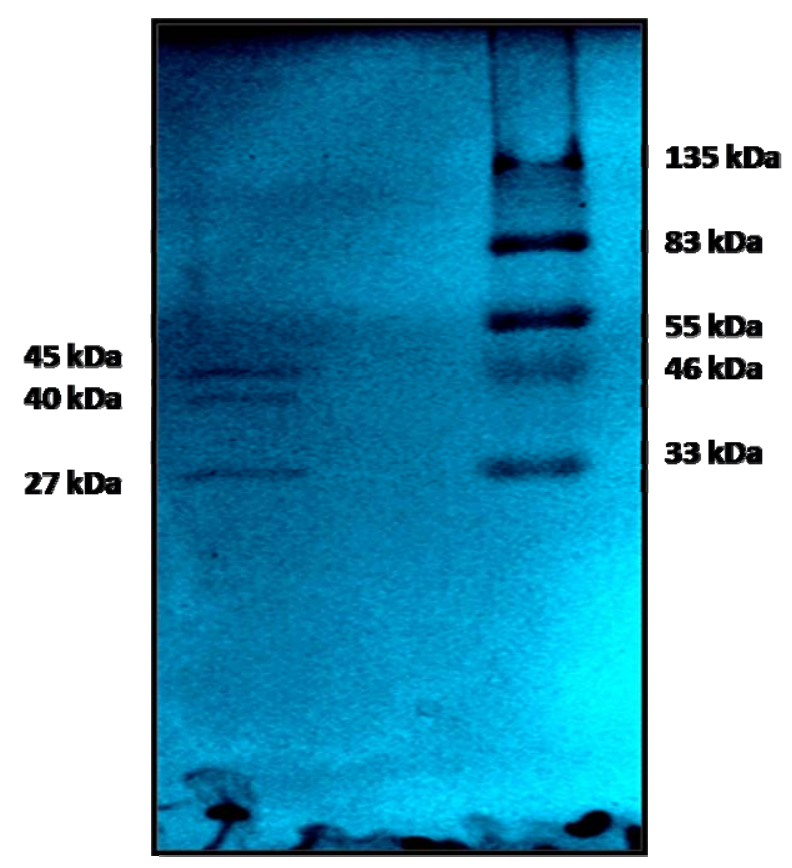

Figure 8. SDS-PAGE gel image of PPUDV phage proteins. Lane 1 shows three bands and lane 2, empty well with no phage sample. Lane 3 contains high molecular weight proein ladder (Sigma/S8320). As shown, at least three major bands $(27,40$ and $45 \mathrm{kDa})$ were detected.

mately $27 \mathrm{KDa}, 40 \mathrm{KDa}$ and $45 \mathrm{KDa}$.

\section{Discussion}

\subsection{Bacteriophages PPUDV and PPURV Genome Characterizations}

Dairy products are essential components in food industries and individual nutrition in Palestine. The quality of dairy products is quite critical and any contamination is considered detrimental and results in major economic losses. Contamination that is caused by bacteriophages generally decreases the quality of food products and is considered undesirable by dairy industries.

We reported the isolation of two bacteriophages from a traditional dairy product called laban jameed: a dsRNA PPURV and ssDNA PPUDV hosting on Bacillus amyloliquefaciens and Lactobacillus helveticus, respectively.

The majority of identified Bacillus amyloliquefaciens and Lactobacillus helveticus bacteriophage genomes belong to dsDNA [25-28]. However, little is known about dsRNA and ssDNA bacteriophages that host on Bacillus amyloliquefaciens and Lactobacillus helveticus strains. A dsDNA Lactobacillus helveticus with genome size 36,566 bp from Grana Padano cheese product was isolated [28]. Also, Sechaud et al. [26] characterized 35 cheese whey Lactobacillus helveticus dsDNA bacteriophages, but without providing information on their genome size. Most lactic acid bacteriophages are believed to be dsDNA
[5,27]. In addition, the isolation of 235 baceriophages affecting $L$. helveticus, L. delbrueckii subsp bulgaricus and L. delbrueckii subsp lactis strains, all with dsDNA and belonged to Siphoviridae, Myoviridae and Podoviridae were also described [27].

There are no reports of dsRNA bacteriophages that host on Bacillus amyloliquefaciens, although a dsDNA PBA12 Bacillus amyloliquefaciens bacteriophage was isolated from soil [25]. While Qiao et al. (2010) [29] described a dsRNA bacteriophage from radish leaves with genome size of 12684 bp hosting on Pseudomonas syringae bacteria. But so far, this study represents the first isolation of dsRNA phage that hosts on Bacillus amyloliquefaciens and ssDNA phage that hosts on Lactobacillus helveticus from dairy jameed food product. The bacteriophage genomes were isolated under reducing conditions to minimize degradation. The $\beta$-mercaptoethanol was added to inhibit the activity of DNase and RNase degrading enzymes by weakening their disulfide bonds [12].

To liberate phage genomes from DNA and RNA binding proteins, phage proteins were denatured and precipitated through the addition of $\mathrm{NaOH}$ and SDS and the phage genomes were precipitated from the supernatant through the addition of sodium acetate in the presence of $\beta$-mercaptoethanol as reported by other studies $[14,30]$. The PPUDV phage was found to be a DNA genome as no bands appeared on the $0.7 \%$ agarose gel when treated with DNase. This is in contrast to PPURV phage which was insensitive to DNase. Unlike PPUDV, it was responsive to RNase digestion as observed on the agarose gel (Figures 5(a) and (b)). Both PPUDV and PPURV genomes appeared to have the same sizes, approximately $20 \mathrm{~kb} \pm 1 \mathrm{~kb}$ as observed on agarose gel using a $23 \mathrm{~kb}$ ladder.

The nature of the bacteriophage genomes was further studied. The RNA genome was determined to be a dsRNA (Figure 6(a)), whereas the DNA genome was a ssDNA genome (Figure 6(b)). There are other assays, such as the Hyperchromicity test, ds/ssRNase specific enzyme degradation and RNase III specific for breaking down dsRNA that were reportedly used to differentiate between $\mathrm{ds} / \mathrm{ss}$ genomes, but these methods were reported to possess low efficiency in working on small amounts of RNA [13,30]. In this study, the RNase A assay was preferred and used. The RNase A digests both ssRNA and dsRNA under low $\mathrm{NaCl}$ concentration $(0.1 \mathrm{M})$, while it digests only ssRNA under high $\mathrm{NaCl}$ concentration $(0.3 \mathrm{M})$ [13-17,30,31]. A previous study reported the resistance of dsRNA of viruses infected plant and fungi to RNase A treatment under $0.3 \mathrm{M} \mathrm{NaCl}$ even after $24 \mathrm{~h}$ incubation [13]. Following treatment with high salt concentration, clear bands were still visible, but disappeared under low $(0.1 \mathrm{M})$ salt treatment. In addition, ssRNA extracted from other viruses was also examined. It completely disappeared under 0.1 
$\mathrm{M}$ and $0.3 \mathrm{M} \mathrm{NaCl}$ treatments [13]. The PPUDV bacteriophage genome, on the other hand, was a ssDNA. The ssDNAs are usually smaller in size than dsDNAs, thus having more fragile structures and are expected therefore to run much faster on agarose gels. The heated PPUDV genome migrated similarly to the un-boiled PPUDV genome on the gel, thus confirming its ssDNA identity. The single strandedness entity was further confirmed by the resistance of genomes to restriction enzyme treatment that cut dsDNA, no bands were detected in both reactions incubated at $8 \mathrm{~h}$ or $16 \mathrm{~h}$ (data not shown).

The ssDNA phage genomes are mostly related to either the Microviridae, circular ssDNA genomes with nonenveloped and isometric shapes, or Inoviridae families, circular ssDNA genomes with nonenveloped and filamentous shapes as appeared by morphological studies using the electron microscope $[32,33]$. Phages that belong to the Cystoviridae family are dsRNA and possess segmented genomes with enveloped capsids and spherical shapes for the phage genomes. However, up to $2009,88 \%$ of completely sequenced genomes in GenBank phage databases are related to dsDNA, mainly distributed among the Caudoviridae orders. The PPUDV and PPURV bacteriophages are therefore possibly belong to the Microviridae, or Inoviridae (ssDNA nucleic acid) or Cystoviridae (dsRNA) family, respectively.

To identify the phases of bacteriophage infection, one step growth curves were constructed. These curves were performed using the double layer plaque assay, a commonly used and highly accurate, fast and easy to handle method [21]. It comprises an agar layer at the plate surface, overlaid with another soft layer $(0.7 \%)$ of agar containing a phage-bacterial suspension. The phage-bacterial suspension is first incubated at $37^{\circ} \mathrm{C}$ to ensure phage adsorption to bacteria, then the soft agar is added in a sterility conditions to avoid any other microorganism contaminations. The latent period, burst period and burst size are then determined.

The latent period illustrates the time period from the adsorption of phage to the host bacteria, until the onset of cell lysis and burst. Host cells rapidly lyse and release infective phage at burst period, occurring after the latent period. The average number estimated for phage progeny to be formed per infected bacterial host cell symbolizes the burst size (Figure 7). Results are recorded as the mean of three trials; measures of PFUs were approximately conserved. This means the relationship between phage titer and phage infection on the related host cells are the same in the three trials. Both PPURV and PPUDV bacteriophages have long latent periods. This indicates that further conditions should be manipulated as to detect optimum bacteriophage activity after infecting their host bacteria. Thus, such conditions could be the culture media itself, as skim milk broth and agar that were used. Other studies preferred the MRS broth media being used for the detection of dairy bacteriophages $[34,35]$.

Three major protein bands appeared for PPUDV bacteriophage with estimated molecular weights of approximately, 27, 40 and $45 \mathrm{kDa}$ (Figure 8). These results indicate that aggregations of several proteins accumulate at each band and/or that some proteins are repetitive copies encoded from the same gene. This is very common in viruses, for example, the capsid surface proteins are usually repetitive of small number of genes [36]. For PPURV bacteriophage, it was difficult to obtain good resolution of the total PPURV proteins (data not shown). This is probably due to the fact that RNA binding proteins are susceptible to degradation.

\subsection{Bacterial Hosts of PPUDV and PPURV}

The molecular characterization was used to identify the two host bacteria that were susceptible to bacteriophage lysis. Two phylogenetic markers that are universally distributed in bacteria and commonly used in bacterial strain identifications, the 16S rRNA and recA genes were targeted [37-39]. The16S rRNA is used as a useful marker in bacterial characterization as it has conserved sequence and function among bacteria, though it shows several limitations due to its inability to differentiate between closely related species that share $99 \%$ or higher sequence identity, like in some LAB strains [38]. Such inability was clearly observed in the case of the $L$. plantarum and $L$. pentosus [38]. Therefore, to further confirm the identity of the host bacteria in this study, the $r e c A$ gene was also used as a marker commonly used in lactic acid bacterial identifications. In this regard, the recA gene has a fundamental advantage over the gene encoding the 16S rRNA, its ability to differentiate closely related species.

Sequence analysis and GenBank blast of the two marker genes used for the identification of $\mathrm{BC} 4$ and $\mathrm{BC} 1$ revealed their identities as Bacillus amyloliquefaciens for BC4 and Lactobacillus helveticus for the BC1 (Figures 3 and 4). The $16 \mathrm{~S} r R N A$ was less informative in determining the relatedness of the $\mathrm{BC} 4$ bacteria. Using the highest maximum identity score, it was initially difficult to determine whether $\mathrm{BC} 4$ was a close relative to Bacillus vallismortis, or Bacillus subtilis, or Bacillus amyloliquefaciens. The use of the recA easily confirmed, however, the identity of the $\mathrm{BC} 4$ host to be more closely related to Bacillus amyloliquefaciens (Figure 3). The B. amyloliquefaciensis is a gram positive bacteria, discovered and normally found in soil. It is considered a useful industrial microorganism, representing, for example, an ample source for producing amylase enzyme commercially used in starch hydrolysis $[40,41]$. It is also a source of protease enzyme that catalyzes the breakdown of proteins and is used in detergent industries [40]. There is no previous study to report the natural presence of the B. amylolique- 
faciens in dairy products and that it plays a role in milk fermentation similar to LAB. However, it was shown to be a useful source for a milk-clotting enzyme in some industrial dairy processing fermentations [42] and in the fermentation of other food products, such as soybeanfermented food [43]. Otherwise, the explanation for its existence is to be a result of jameed contamination with soil. During the process of jameed drying, it is usually kept uncovered on the ground in sunny areas for a few days to reduce the moisture content and so it is possible that this strain is just a contaminant from the nearby soil. Milk microbial contaminants belong mostly to the genus Bacillus, including the B. amyloliquefaciens and the $B$. cereus, which produce a toxin that can cause diarrhea and another that causes vomiting [44]. Bacillus cereus spores are heat-resistant and may survive pasteurization. There have even been very rare cases linked to dried milk and dried infant formulas [45]. The source of contamination in dairy products could be multifarious, like soil, air and water $[44,46]$. The dairy industries implement several strategies to reduce contaminations, such as pasteurization under high temperature, but even so, contamination still could occur due to some microbial heat resistant spores. Dairy processing that relies on traditional methods is subject to a higher possibility of contaminations. Traditional laban jameed production is dependent on personnel in milk transport and processing under mostly unsterile environment and storage conditions.

The $\mathrm{BC} 1$ host was clearly identified to be a close relative to the Lactobacillus helveticus strains (Figure 4). This strain is one of the common lactic acid producing gram positive bacteria [6,47]. It helps in maintaining good food flavor and acidic conditions that inhibit the spoilage of milk products. Furthermore, the relationships of PPUDV and BC1 and PPURV and BC4 host bacteria with other related species were determined by the phylogenetic trees, which were constructed using the highest identities as appeared by the two markers, recA and $16 \mathrm{~S} r R N A$ sequence blasts. The trees included the most common Lactobacillus bacteria that occupy the highest percentage of the microbial population; L. pentosus, L. casei, L. fermentum, L. plantarumand L. paraplantarum, while those with lower identities were masked and excluded.

\section{Conclusions}

Several studies demonstrated the isolation of dairy product bacteriophages, but so far no phages have been isolated from laban jameed. Most of the isolated dairy bacteriophages were characterized as dsDNA. To our knowledge, this study reports the first isolation of ssDNA and dsRNA bacteriophages from laban jameed dairy product.

Moreover, as there is a significant increase in antibiotic resistance among bacteria, there is a notion to use phage therapy as an alternative for antibiotics. The iso- lated bacteriophages from jameed milk may have the potential for future uses as alternatives for antibiotics if they prove to lyse pathogenic bacteria, particularly those that exist in close proximity to milk, such as those causing mastitis disease. It is believed that this study may provide further information on the complex interactions between phages and their hosts, and promote studies on phage therapy.

\section{Acknowledgements}

The authors would like to thank Dr. Robin Abu Ghazaleh, Dr. Rami Arafeh, and Dr. Sameer Barghouthi for carefully reading the manuscript and Dr. Yaqoub Ashhab for advice, Mrs. Amal Abu Rayan for carrying out the sequencing, and Mrs. Asma Tamimi and Mr. Hasan Altarada for technical support.

\section{REFERENCES}

[1] A. Alomari, M. J. Quasem and A. S. Mazahreh, "Microbiological Analysis of Solar and Freeze-Dried Jameed Produced from Cow and Sheep Milk with the Addition of Carrageenan Mix to the Jameed Paste," Pakistan Journal of Nutrition, Vol. 7, No. 6, 2008, pp. 726-729. http://dx.doi.org/10.3923/pjn.2008.726.729

[2] A. S. Mazahreh, F. A. Al-Shawabkeh and M. J. Quasem, "Evaluation of the Chemical and Sensory Attributes of Solar and Freeze-Dried Jameed Produced from Cow and Sheep Milk with the Addition of Carrageenan Mix to the Jameed Paste," American Journal of Agricultural and Biological Sciences, Vol. 3, No. 3, 2008, pp. 627-632. http://dx.doi.org/10.3844/ajabssp.2008.627.632

[3] A. Al-Saed, R. Al-Groum and M. Al-Dabbas, "Implementation of Hazard Analysis Critical Control Point in Jameed Production," Food Science and Technology International, Vol. 18, No. 3, 2012, pp. 229-239. http://dx.doi.org/10.1177/1082013211427783

[4] A. Bosch, M. Golowczyc, A. Abraham, G. Garrote, G. De Antoni and O. Yantorno, "Rapid Determination of Lactobacilli Isolated from Kefir Grains by FT-IR Spectroscopy," International Journal of Food Microbiology, Vol. 111, No. 3, 2006, pp. 280-287.

http://dx.doi.org/10.1016/j.ijfoodmicro.2006.05.010

[5] G. De Antoni, M. Zago, O. Vasek, G, Giraffe, D. Carminati, B. M. Marco, J. Reinheime and V. Suarez, "Lactobacillus plantarum Bacteriophages Isolated from Kefir Grains: Phenotypic and Molecular Characterization," Journal of Dairy Research, Vol. 77, No. 1, 2010, pp. 7-12. http://dx.doi.org/10.1017/S0022029909990203

[6] B. M. Marcó, S. Moineau and A. Quiberoni, "Bacteriophages and Dairy Fermentations," Landes Bioscience, Vol. 2, No. 3, 2012, pp. 149-158.

[7] B. Del Rio, G. A. Binetti, C. M. Martín, M. Fernández, H. A. Magadán and A. M. Alvarez, "Multiplex PCR for the Detection and Identification of Dairy Bacteriophages in Milk," Food Microbiology, Vol. 24, No. 1, 2007, pp. 75-81. http://dx.doi.org/10.1016/j.fm.2006.03.001 
[8] S. Mills, P. R. Ross, H. Neve and A. Coffey, "Bacteriophage and Anti-Phage Mechanisms in Lactic Acid Bacteria," Microbiological and Functional Aspects, 2011, pp. $165 \mathrm{~S}-186 \mathrm{~S}$.

[9] N. W. I. Haq, N. M. Akhtar, S. Andleeb and I. Qadri, "Bacteriophages and Their Implications on Future Biotechnology: A Review," Virology Journal, Vol. 9, No. 9, 2012, pp. 1-8. http://dx.doi.org/10.1186/1743-422X-9-9

[10] S. J. Labrie, J. E. Samson and S. Moineau, "Bacteriophage resistance mechanisms," Nature Reviews Microbiology, Vol. 8, 2010, pp. 317-327. http://dx.doi.org/10.1038/nrmicro2315

[11] E. J. Garneau and S. Moineau, "Bacteriophages of Lactic Acid Bacteria and Their Impact on Milk Fermentations," Microbial Cell Factories, Vol. 10, Supl. 1, 2011, pp. 1-10. http://dx.doi.org/10.1186/1475-2859-10-S1-S20

[12] I. Manasrah and S. Barghouthi, "Multiplex PCR Detection of Bacterial and Viral Meningitis in Cerebrospinal Fluid," The 7th Palestinian Conference of Laboratory Medicine, Bethlehem, 15-17 March 2012.

[13] J. T. Morris and A. J. Dodds, "Isolation and Analysis of Double-Stranded RNA from Virus-Infected Plant and Fungal Tissue," Phytopathology, Vol. 69, No. 8, 1979, p. 855.

[14] G. W. P. Chu and G. E. Westaway, "Replication Strategy of Kunjin Virus: Evidence for Recycling Role of Replicative Form RNA as Template in a Semi Conservative and Asymmetric Replication," Virology Journal, Vol. 140, No. 1,1985 , pp. 68-79. http://dx.doi.org/10.1016/0042-6822(85)90446-5

[15] E. G. Westaway, A. A Khromykh and J. M. Mackenzie, "Nascent Flavivirus RNA Colocalized in Situ with Double-Stranded RNA in Stable Replication Complexes," Virology Journal, Vol. 258, No. 1, 1999, pp. 108-117. http://dx.doi.org/10.1006/viro.1999.9683

[16] P. Targett-Adams, S. Boulant and J. McLauchlan, "Visualization of Double-Stranded RNA in Cells Supporting Hepatitis C Virus RNA Replication," Journal of Virology, Vol. 82, No. 5, 2008, pp. 2182-2195. http://dx.doi.org/10.1128/JVI.01565-07

[17] A. Ablasser, F. Bauernfeind, G. Hartmann, E. Latz, K. A. Fitzgerald and V. Hornung, "RIG-I-Dependent Sensing of Poly (dA:dT) through the Induction of an RNA Polymerase III-Transcribed RNA Intermediate," Nature Immunology, Vol. 10, No. 10, 2009, pp. 1065-1073. http://dx.doi.org/10.1038/ni.1779

[18] J. Sambrook and W. D. Russel, "Molecular Cloning Laboratory Manual," Cold Spring Harbor Laboratory Press, Vol. 3, 2001.

[19] A. M. Al-Manasra and F. Al-Razem, "Cloning and Expression of a New Bacteriophage (SHPh) DNA Ligase Isolated from Sewage," Journal of Genetic Engineering and Biotechnology, Vol. 10, No. 2, 2012, pp. 177-184. http://dx.doi.org/10.1016/j.jgeb.2012.05.005

[20] Z. Lu, F. Breidt Jr., P. H. Fleming, E. Altermann and R. T. Klaenhammer, "Isolation and Characterization of a Lactobacillus plantarum Bacteriophage, AJL-1, from a $\mathrm{Cu}-$ cumber Fermentation," International Journal of Food Microbiology, Vol. 84, No. 2, 2003, pp. 225-235.
http://dx.doi.org/10.1016/S0168-1605(03)00111-9

[21] L. Moce-Llivina, F. Lucena and J. Jofre, "Double-Layer Plaque Assay for Quantification of Enteroviruses," Applied and Environmental Microbiology, Vol. 70, No. 5, 2004, pp. 2801-2805. http://dx.doi.org/10.1128/AEM.70.5.2801-2805.2004

[22] E. G. Felis and F. Dellaglio, "Taxonomy of Lactobacilli and Bifidobacteria," Current Issues Intestinal Microbiology, Vol. 8, No. 2, 2005, pp. 44-61.

[23] C. Canchaya J. M. Claesson, F. G. Fitzgerald, D. Sinderen and W. P. O'Toole, "Diversity of the Genus Lactobacillus Revealed by Comparative Genomics of Five Species," Microbiology, Vol. 152, No. 11, 2006, pp. 3185-3196. http://dx.doi.org/10.1099/mic.0.29140-0

[24] A. M. W. Mullan, "Plaque Formation," 2002. http://www.dairyscience.info/enumeration-of-lactococcalbacteriophages/plaque-formation.html

[25] R. J. Erickson and F. E. Young, "Characterization of a Virulent Bacteriophage for Bacillus subtilis (var. Amyloliquefaciens)," Applied Microbiology, Vol. 27, No. 3, 1974, pp. 600-602.

[26] L. Sechaud, M. Rousseau, B. Fayard, M. L. Callegari, P. Queen and J. P. Accolas, "Comparative Study of 35 Bacteriophages of Lactobacillus helveticus: Morphology and Host Range," Applied and Environmental Microbiology, Vol. 58, No. 3, 1991, pp. 10-11.

[27] M. Villion and S. Moniteau, "Bacteriophages of Lactobacillus," Frontiers in Bioscience, Vol. 14, No. 5, 2009, pp. 1661-1683. http://dx.doi.org/10.2741/3332

[28] M. Zago, E. Scaltriti, L. Rossetti, L. Guffanti, A. Armiento, E. M . Fornasari, S. Grolli, D. Carminati, E. Brini, P. Pavan, A. Felsani, A. D’Urzo, S. Moles, B. J. Claude, R. Grandori, R. Ramoni and G. Giraffa, "Genome Characterization of the Dairy Lactobacillus helveticus Bacteriophage $\Phi A Q 113, "$ Applied Environmental Microbiology, Vol. 79, No. 15, 2013, pp. 1-29. http://dx.doi.org/10.1128/AEM.00620-13

[29] X. Qiao, Y. Sun, J. Qiao, F. Di Sanzo and L. Mindich, "Characterization of $\Phi 2954$, a Newly Isolated Bacteriophage Containing Three dsRNA Genomic Segments," BMC Microbiology, Vol. 10, No. 55, 2010, pp.1-7. http://dx.doi.org/10.1186/1471-2180-10-55

[30] G. V. Edy, M. Szekely, T. Loviny and C. Dreyer, "Action of Nucleases on Double-Stranded RNA," European Journal of Biochemistry, Vol. 61, No. 2, 1976, pp. 563-572. http://dx.doi.org/10.1111/j.1432-1033.1976.tb10051.x

[31] R. M. Dayer, O. Ghayour and S. M. Dayer, "Mechanism of the Bell-Shaped Profile of RibonucleaseA Activity: Molecular Dynamic Approach," Protein Journal, Vol. 31, No. 7, 2012, pp. 573-579. http://dx.doi.org/10.1007/s10930-012-9435-4

[32] H.-W. Ackermann, "Bacteriophage Taxonomy," Microbiology Australia, 2011, pp. 90-94.

[33] www.ictvonline.org/virusTaxonomy.asp

[34] T. S. Abedon, "Selection for Bacteriophage Latent Period Length by Bacterial Density: A Theoretical Examination," Microbial Ecology, Vol. 18, No. 2, 1989, pp. 79-88. http://dx.doi.org/10.1007/BF02030117 
[35] J. A. Cann, "Principles of Molecular Virology," 4th Edition, Academic Press, 2005, p. 352.

[36] S.C. Harrison, "Viruses," Current Opinion in Structural Biology, Vol. 2, No. 2, 1992, pp.293-299. http://dx.doi.org/10.1016/0959-440X(92)90160-9

[37] M. Collins, U. Rodrigues, C. Ash, M. Aguirre, E. A. J. Farrow, M. A. Murcia, A. B. Phillips, M. A. Williams and S. Wallbanks, "Phylogenetic Analysis of the Genus Lactobacillus and Related Lactic Acid Bacteria as Determined by Reverse Transcriptase Sequencing of $16 \mathrm{~S}$ rRNA," Federation of European Microbiological Societies, Vol. 77, No. 1, 1991, pp. 5-12. http://dx.doi.org/10.1111/j.1574-6968.1991.tb04313.x

[38] S. Torriani, E. G. Felis and F. Deliaglio, "Differentiation of Lactobacillus plantarum, L. pentosus and L. paraplantarum by recA Gene Sequence Analysis and Multiplex PCR Assay with recA Gene-Derived Primers," Applied and Environmental Microbiology, Vol. 67, No. 8, 2001, pp. 3450-3454. http://dx.doi.org/10.1128/AEM.67.8.3450-3454.2001

[39] M. M. Patil, A. Pal, A. Anand and V. K. Ramana, "Isolation and Characterization of Lactic Acid Bacteria from Curd and Cucumber," Indian Journal of Biotechnology, Vol. 9, No. 2, 2010, pp. 166-172.

[40] G. F. Priest, M. Goodfello, A. L. Shute and W. C. R. Berkely, "Bacillus amyloliquefaciens sp. nov., nom. rev," International Journal of Systematic Bacteriology, Vol. 37, No. 1, 1987, pp. 69-71. http://dx.doi.org/10.1099/00207713-37-1-69

[41] D. Gangadharan, S. Sivaramakrishnan, K. M. Nampoothiri and A. Pandey, "Solid Culturing of Bacillus amyloliquefaciens for Alpha Amylase Production," Food Technology and Biotechnology, Vol. 44, No. 2, 2006, pp. 269-274.

[42] Z. Ding, W. Wang, B. Wang, A. Ouyang, Si. Xiao, Y.
Wang, S. Liu, M. Ding, L. Zhang and G. Shi, "Production and Characterization of Milk-Clotting Enzyme from $\mathrm{Ba}$ cillus amyloliquefaciens JNU002 by Submerged Fermentation,"European Food Research \& Technology, Vol. 234, No. 3, 2012, pp. 415-421. http://dx.doi.org/10.1007/s00217-011-1650-2

[43] M.-H. Joo, S.-H. Hur, Y.-S. Han and J.-Y. Kim, "Isolation, Identification and Characterization of Bacillus Strains from the Traditional Korean Soybean-fermented Food Chungkookjang," Journal of Applied Biological Chemistry, Vol. 50, No. 4, 2007, pp. 202-210.

[44] J. M. González, F. Gorgoroso, M. S. Reginensi, A. J. Olivera and J. Bermúdez Polyphasic, "Identification of Closely Related Bacillus Subtilis and Bacillus amyloliquefaciens Isolated from Dairy Farms and Milk Powder," Journal of Microbiology, Biotechnology and Food Sciences, Vol. 2, No. 5, 2012, pp. 2326-2331.

[45] K. J. Boor, "Fluid Dairy Product Quality and Safety: Looking to the Future," Journal of Dairy Science, Vol. 84, No. 1, 2001, pp. 1-11. http://dx.doi.org/10.3168/jds.S0022-0302(01)74445-1

[46] A. Coorevits, V. De Jonghe, J. V. androemme, R. Reekmans, J. Heyrman, W. Messens, P. De Vos and M. Heyndrickx, "Comparative Analysis of the Diversity of Aerobic Spore-Forming Bacteria in Raw Milk from Organic and Conventional Dairy Farms," Systematic and Applied Microbiology, Vol. 31, No. 2, 2008, pp. 126-140. http://dx.doi.org/10.1016/j.syapm.2008.03.002

[47] L. Slattery, J. O'Callaghan, F. G. Fitzgerald, T. Beresford and P. R. Ross, "Invited Review: Lactobacillus helveticus-A Thermophilic Dairy Starter Related to Gut Bacteria," Journal of Dairy Science, Vol. 93, No. 10, 2010, pp. 4435-4454. http://dx.doi.org/10.3168/jds.2010-3327 